\title{
Pellet Dosing Unit
}

National Cancer Institute

\section{Source}

National Cancer Institute. Pellet Dosing Unit. NCI Thesaurus. Code C48525.

A dosing unit equal to the amount of active ing redient(s) contained in a pellet. 